\title{
Stress in the kidney is the road to pERdition: is endoplasmic reticulum stress a pathogenic mediator of diabetic nephropathy?
}

\author{
Aowen Zhuang' and Josephine M Forbes ${ }^{1,2}$ \\ ${ }^{1}$ Glycation and Diabetes Group, Mater Research Institute - The University of Queensland, \\ Translational Research Institute, 37 Kent Street, Woolloongabba, South Brisbane, Queensland, Australia \\ ${ }^{2}$ Mater Clinical School, The University of Queensland, South Brisbane, Queensland, Australia
}

Correspondence should be addressed to J M Forbes Email josephine.forbes@ mater.uq.edu.au

\begin{abstract}
The endoplasmic reticulum (ER) is an organelle that primarily functions to synthesise new proteins and degrade old proteins. Owing to the continual and variable nature of protein turnover, protein synthesis is inherently an error-prone process and is therefore tightly regulated. Fortunately, if this balance between synthesis and degradation is perturbed, an intrinsic response, the unfolded protein response (UPR) is activated to restore ER homoeostasis through the action of inositol-requiring protein 1, activating transcription factor 6 and PKR-like ER kinase transmembrane sensors. However, if the UPR is oversaturated and misfolded proteins accumulate, the ER can shift into a cytotoxic response, a physiological phenomenon known as ER stress. The mechanistic pathways of the UPR have been extensively explored; however, the role of this process in such a synthetic organ as the kidney requires further clarification. This review will focus on these aspects and will discuss the role of ER stress in specific resident kidney cells and how this may be integral in the pathogenesis and progression of diabetic nephropathy (DN). Given that diabetes is a perturbed state of protein turnover in most tissues, it is important to understand if ER stress is a secondary or tertiary response to other changes within the diabetic milieu or if it is an independent accelerator of kidney disease. Modulators of ER stress could provide a valuable tool for the treatment of DN and are under active investigation in other contexts.
\end{abstract}

\author{
Key Words \\ - endoplasmic reticulum stress \\ - diabetic nephropathy \\ - mTORC1 \\ - podocyte \\ - proximal tubule cell
}

\section{Introduction}

A tightly balanced homoeostasis exists between the synthesis and degradation of proteins, which is maintained in the endoplasmic reticulum (ER). When imbalance occurs in either one or both of these facets, the ER activates coordinated adaptive responses known as the unfolded protein response (UPR) and the ERassociated degradation (ERAD) pathway in an attempt to restore balance in the ER. However, when these responses are saturated, the misfolded proteins accumulate in the ER, and cells develop a detrimental condition referred to as ER stress. The principles of the UPR are now relatively well defined (Ron \& Walter 2007, Hasnain et al. 2012, Hetz 2012), and the mechanisms of the signal transducers involved in the activation of this pathway have already been the subject of detailed reviews (Ron \& Walter 2007). However, several key questions remain 
unanswered: i) how the UPR system integrates within specific resident cells of the kidney, ii) how diseases such as diabetes can promote an imbalance at these sites and iii) whether this ultimately leads to ER stress-induced pathology culminating in nephropathy. This review summarises recent developments in these areas and highlights new insights into translational applications into the clinical environment.

\section{Function of the ER}

The ER functions as a site of synthesis, folding and maturation of secreted, luminal and transmembrane proteins. Synthesis of unfolded polypeptide chains occurs in the rough ER where they undergo a maturation process, mediated by ER-resident enzymes and chaperones to form a stoichiometric stable conformation that is both energetically efficient and biologically active (Dobson 2003, Araki \& Nagata 2011).

During the synthesis of new proteins, the stoichiometry of the amino acid chains can be altered by post-translational modifications, thereby profoundly affecting the energy signature and conformation of the folded protein. The role of post-translational modifications in the development of disease is becoming more apparent, particularly in chronic conditions such as diabetes (van Lummel et al. 2013), due to their effects on the generation of inappropriately folded proteins, observed most vividly in congenital disorders of glycosylation (Cylwik et al. 2013). Subsequently, the maturation of these nascent proteins is further dependent on the appropriate intracellular concentrations of calcium, glucose and ATP, as well as the redox environment (Kaufman et al. 2002); all of which function as ER quality-control factors. When proteins are both correctly folded and carry the appropriate post-translational modifications, the protein exits the ER and progresses through the secretory pathway to the Golgi body. When folded inappropriately, proteins accumulate within the ER, where UPR pathways are activated or terminally misfolded proteins are retro-translocated from the ER into the cytoplasm and undergo proteasome degradation in the ERAD pathway.

Protein homoeostasis within cells is particularly complex in nature as a balance is forged among constant turnover, the synthesis of new proteins and the degradation of old proteins, as well as the influx of new proteins and precursors from the extracellular environment. Unfortunately, protein synthesis is inherently an error-prone process. Nevertheless, the dynamic nature of the ER allows cells to adjust their protein-folding capacity in response to fluctuations in the environment through transmembrane sensors that face the ER lumen and effectors that signal to other compartments of the cell, ensuring that secreted proteins are maintained at a high fidelity and at the correct concentrations to maintain protein homoeostasis.

\section{Triggering the UPR}

In mammalian cells, there are three major UPR pathways, activated by transmembrane sensors located in the ER membrane. These three major pathways are the inositolrequiring protein 1 (IRE1), activating transcription factor 6 (ATF6) and the PKR-like ER kinase (PERK)-mediated response. When protein synthesis and degradation in the ER are under homoeostatic balance, these three sensors are inactive and are suggested to be either inherently inactive until unfolded proteins activate the sensors, maintained in an inactive state by the ER chaperone BiP, or regulated by hybrid of both of these mechanisms (Ron \& Walter 2007). When activated, these pathways elicit several physiological responses in order to counteract the increased accumulation of inappropriately folded proteins. Ultimately, the purpose of the UPR pathway is to prevent an overabundance of misfolded proteins in the ER, which would consequently result in ER stress and potentially cell death.

As misfolded proteins begin to accumulate in the ER, pathways of the UPR are activated. The first identified stress transducer IRE1 (Cox et al. 1993, Mori et al. 1993) undergoes oligomerisation following the accumulation of misfolded proteins and trans-autophosphorylates, which allosterically activates IRE1 endoribonuclease activity via a conformational change (Papa et al. 2003). IRE1-mediated sequence-specific cleavage is targeted at X-box-binding protein 1 (XBP1) mRNA causing a frame shift in the coding sequence. A frame shift in XBP1 mRNA leads to the manufacture of the potent transcriptional activator (XBP1s), which activates genes encoding ER chaperones, enzymes that promote protein folding, maturation, secretion and ERAD components in an attempt to decrease ER load and relieve ER stress (Hollien \& Weissman 2006, Glimcher 2010). In parallel, ATF6 traffics to the Golgi in the presence of misfolded proteins, where it is cleaved by proteases S1P and S2P (Ye et al. 2000) revealing a cytosolic fragment (ATF6n), which has a DNA-binding domain. ATF6 $n$ subsequently migrates to the nucleus and in a similar manner to $X B P 1$, functions as a transcriptional

Published by Bioscientifica Ltd. 


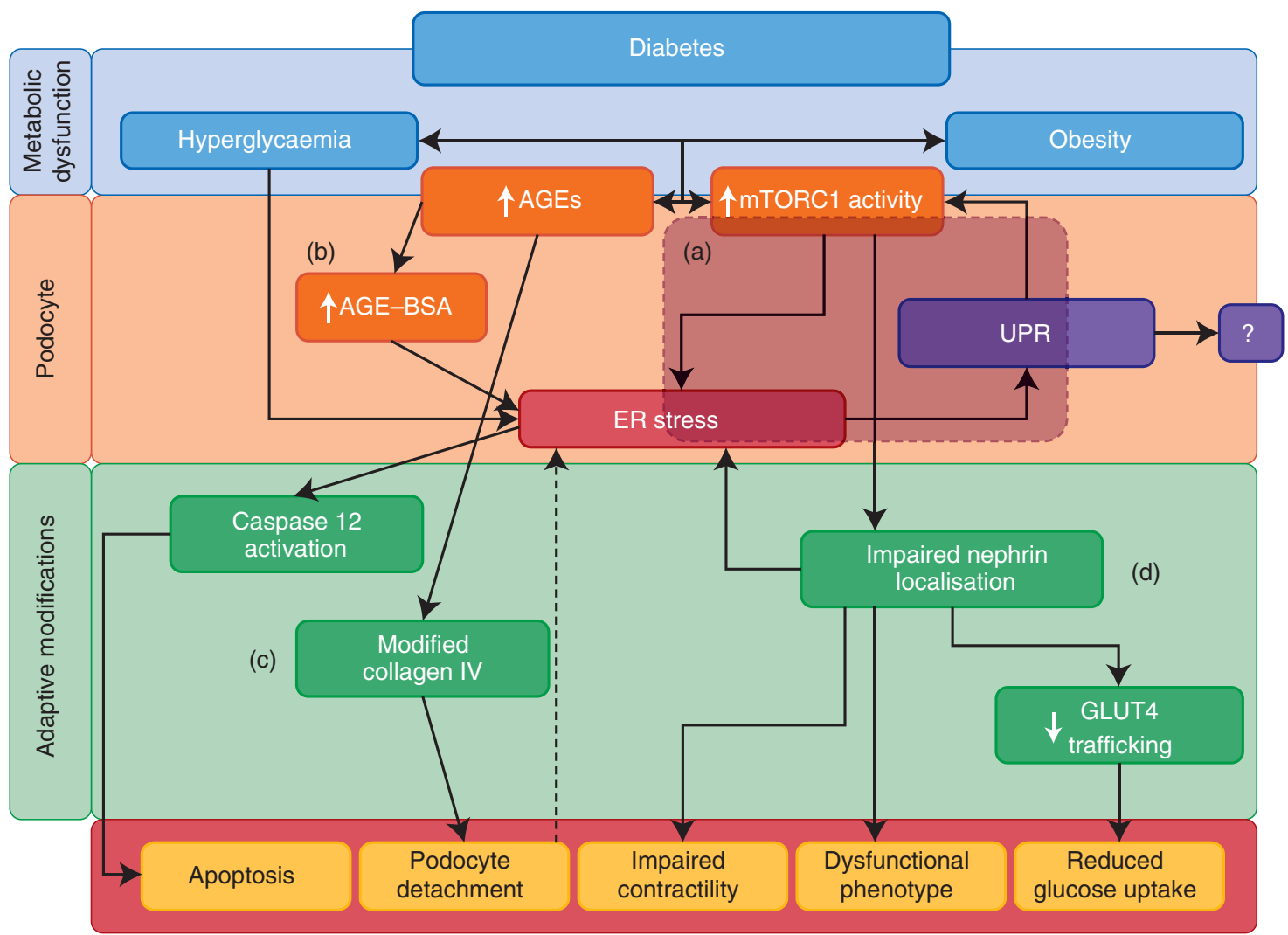

\section{Figure 1}

A summary of the proposed mechanisms of ER stress-induced podocyte dysfunction. (a) Glomerular stress events, mediated by diabetes in this case, and the subsequent metabolic and catabolic changes perturb the balance among mTORC1, the ER and UPR. (b) AGE-BSA induces podocyte apoptosis mediated by caspase 12 activation (Chen et al. 2008, 2011). (c) AGE-modified collagen IV contributes to podocyte detachment or dysfunction (Chuang et al. 2007) and ER stress leading to the development of podocyte

activator for proteins that assist in resolution of ER stress by increasing ER capacity (Haze et al. 1999).

Unlike the other two signal transducers, PERK phosphorylation activates a substrate known as eukaryotic translation initiation factor $2 \alpha$ (eIF $2 \alpha$ ). Activation of eIF $2 \alpha$ reduces ER stress not by increasing the ER potential, rather eIF $2 \alpha$ reduces the load on the ER by inhibiting translation of new proteins from mRNA, leading to a reduction in overall protein synthesis through the inhibition of AUG codon recognition at the ribosomal level (Harding et al. 1999).

The pathways of the UPR are essential in maintaining normal physiological functions, particularly in cells with a high rate of protein synthesis (kidney tubule cells (Goldspink \& Kelly 1984, Tessari et al. 1996)) or secretory function (pancreatic $\beta$-cells and liver cells (Rutkowski \& Hegde 2010)). Additionally, as the UPR is conserved dysfunction. Obesity is probably a factor contributing to dysfunctional mTORC1 activity, given that mTORC1 activity is increased in the glomerulus in obese $d b / d b$ mice with a targeted genetic insertion of mTORC1 activity when compared with $\mathrm{db} / \mathrm{m}$ mice (Inoki et al. 2011). (d) Chronic changes in mTORC1 activity could be a determinant pathway leading to the development of diabetic nephropathy through various pathological changes to the podocyte (Coward et al. 2007, Inoki et al. 2011).

through many species, perhaps the design of this pathway was intended to be acutely beneficial dependent on the disease conditions, ameliorating damage. Unfortunately, when the UPR is consistently activated such as in the presence of a chronic condition (such as diabetes) or during viral infection where cellular protein machinery is a means for viral replication, this adaptive response of the UPR system develops into a cytotoxic response promoting increased autophagy and apoptosis in an attempt to halt disease progression.

\section{ER stress in diabetes}

The ER stress response is thought to be involved in several pathophysiological developments throughout the progression of diabetes and the associated chronic complications. The relationship between ER stress 
and the regulatory metabolic pathways in the ER is incredibly diverse. However, as the current literature stands, there appears to be a greater focus on ER stress and the downstream response in type 2 diabetes (T2D) when compared with T1D, although this does not reflect the lack of relevance to this disorder as well as its role, in the development of complications associated with diabetes.

\section{Type 2 diabetes}

Obesity is a common comorbidity in individuals with T2D characterised by dysregulation of hepatic glucose production in combination with declining peripheral insulin sensitivity in the face of inadequate insulin secretion by the pancreatic $\beta$-cells. During the progression of T2D, there is an increased demand on the $\beta$-cells for insulin production in order to compensate for the ongoing intolerance. Moreover, an unfortunate eventuality for the majority of obese T2D is the advent of both glucotoxicity and lipotoxicity, where the imbalance between glucose and lipid homoeostasis is a confounding result of nutrient excess as well as other comorbidities such as renal or hepatic disease.

Initial studies implicating ER stress in the pathogenesis of T2D indicated that genetically obese mice $(o b / o b)$ or mice fed on a high-fat diet inducing obesity had increased parameters of the UPR in the liver and adipose tissues (Ozcan et al. 2004). Similarly in insulin-resistant, nondiabetic humans, there are marked increases in the presence of the IRE1 (ERN1) protein, an indicator of the adaptive response of the UPR (Boden et al. 2008). Despite only detecting changes in one arm of the UPR in the aforementioned study, another study cohort of severely obese patients who underwent surgery-assisted weight loss (BMI of 51.3 compared with a BMI of 33.5) exhibited significant decreases in all aspects of the UPR arms in the majority of patients, indicating a significant reduction in ER stress after gastric-bypass-induced weight loss (Gregor et al. 2009). Noteworthy were the concomitant improvements in overall metabolic health afforded to these patients with the associated surgery. Evidently, certain polymorphisms in the ATF6 gene were identified to be associated with T2D and modulation of plasma glucose in certain populations of the Dutch (Meex et al. 2007) and Pima Indians (Thameem et al. 2006). Unfortunately, among indigenous populations, specifically the Pima Indians (Nelson et al. 1996, Lemley 2003) and Australian Aborigines (Hoy et al. 1999, McDonald \& Russ 2003), there is an inherent increased prevalence of diabetic comorbidities of both cardiovascular and renal diseases. Whether genetic polymorphisms resulting in dysfunctional responses to ER stress could provide a basis accompanied by other factors for the accelerated progression of renal disease needs to be further established in these populations. These genetic associations are not constitutive among all ethnic backgrounds, with very little association noted among the certain population groups of the Chinese (Chu et al. 2007, Hu et al. 2011), Caucasian (Chu et al. 2007) and AfricanAmerican (Chu et al. 2007) ethnicities.

Prolonged exposure to nutrient excess in obese individuals promoting an environment of systemic ER stress could synergistically contribute to the pathophysiology of both insulin resistance and hyperglycaemia in obesity and T2D. Each of these would clearly affect diabetic kidney disease where there are clear benefits of strict glycaemic (Patel et al. 2008, Gerstein et al. 2008) and lipid control (Fried et al. 2001, Collins et al. 2003), as well as weight loss and caloric restriction (Gross et al. 2002, Ros et al. 2004). However, it is not certain whether ER stress is a consequence of diabetes or the developed comorbidity of obesity.

\section{Type 1 diabetes}

The traditional notion of T1D as primarily an autoimmune disease in humans is currently being challenged and it is being tentatively labelled as an inflammatory pancreatic-wide disease (Skog et al. 2013). Therefore, this hypothesis raises interesting possibilities that other damage mechanisms such as ER stress as act pathogenic mediators of T1D, given that islets isolated from individuals with T1D have increased levels of ER stress markers (Marhfour et al. 2012). A particularly interesting notion is the integral role of PERK, an ER stress signalling molecule, in maintaining normal pancreatic health and function. Murine models with null mutations in Perk (Eif2ak3) and mutations at the Ser51 phosphorylation site in Eif $2 \alpha$ (Eif2s1) exhibit $\beta$-cell dysfunction and diabetes (Harding et al. 2001, Scheuner et al. 2001, 2005). Additional work has described the necessity for PERK function during the neonatal stage in pancreas development (Zhang et al. 2006). Not only does PERK appear to be essential during the development of the pancreas, but there is evidence that maintenance of normal $\beta$-cell function in the adult pancreas also requires PERK (Gao et al. 2012). Furthermore, a mutation in the EIF2AK3 gene causes an autosomal recessive disease known as Wolcott-Rallison syndrome in humans, who often exhibit presentation of T1D and renal insufficiencies during the neonatal period

Published by Bioscientifica Ltd. 
(Iyer et al. 2004). Interestingly, within the South Indian population, polymorphisms between the regions around the EIF2AK3 locus show an association with T1D susceptibility (Allotey et al. 2004). Evidently when compared with the neighbouring regions, the South Indian population has the highest prevalence of kidney disease (Rajapurkar et al. 2012). It has also been observed that South Indian/Asian migrants have a greater prevalence and faster progression of diabetic nephropathy (DN) when compared with their European counterparts (Samanta et al. 1986, Chandie Shaw et al. 2006). This is particularly noteworthy as it may indicate that in the advent of ER stress a deficiency in PERK function could play a contributing role in the progression of comorbidities, such as DN.

\section{ER stress and DN}

The role of ER stress in diabetic injury is not a new concept, with several indications that the presence of high glucose and free fatty acids in diabetic patients can induce ER stress, implicating ER stress in the development of complications such as retinopathy (Oshitari et al. 2008, Jing et al. 2012) and cardiovascular disease (Beriault \& Werstuck 2012, Xu et al. 2012). However, it has only been recently demonstrated that there has been a focus on the potential role of ER stress in the pathogenesis of DN, with reports identifying the activity of the UPR in podocytes and other kidney cells (Cheng et al. 2006, Liu et al. 2008, Tao et al. 2012). Lindenmeyer et al. (2008) identified the induction of UPR genes in humans with $\mathrm{DN}$ in a manner that is dependent on the degree of kidney injury, where biopsies of patients with established DN exhibited increased levels of XBP1 and ER chaperones (HSPA5/ GRP78 and HYOU1/ORP150), when compared with those with only mild diabetes. Moreover, much like the pancreatic $\beta$-cells, the kidneys could constitutively be a site sensitised for the induction of ER stress, due to the high rates of protein synthesis. Although surprising, in humans, it is estimated that the fractional rates of protein synthesis by the kidneys is approximately $42 \%$ of the total body load daily (Tessari et al. 1996), which is the highest in the body, further indicating that kidney cells could be highly susceptible to ER stress, due to fluctuations in the ER load. It is important to identify the disparate functions of the different resident kidney cells, and understanding how ER stress contributes to DN pathophysiology in the unique cell populations may elucidate novel pharmacological targets for remediating the disease.

\section{ER stress-mediated glomerular injury}

Glomerular epithelial cells (podocytes) play an essential role in the health and function of the glomeruli. The podocytes are insulin-sensitive cells (Coward et al. 2005, Welsh et al. 2010) that contract to limit diuresis, fluxing nutrients into the urine for the primary purpose of nutrient retention and post-prandial utilisation. Unfortunately, the podocyte is a terminally differentiated cell with limited capabilities to regenerate and proliferate following injury, therefore reduced podocyte density is argued to be a crucial determinant in the development and progression of DN (Pagtalunan et al. 1997, Susztak et al. 2006). The induction of ER stress has been elegantly reviewed in primary glomerular diseases (Dickhout \& Krepinsky 2009). However, developing a greater understanding as to how ER homoeostasis is perturbed in these cells during diabetes and the subsequent adaptive responses is warranted.

\section{Mechanisms culminating in a stressed diabetic podocyte ER}

Currently, there are no direct studies investigating the specific role that ER stress plays through the targeted deletion of the ATF6/IRE1/PERK pathways in the podocytes, irrespective of diabetic conditions. Common insults such as the accumulation of advanced glycation end products (AGEs) and the activation of their receptors have been implicated in not only the pathogenesis of DN (Forbes et al. 2003, Wendt et al. 2003, Penfold et al. 2010, Tan et al. 2010) but also the induction of ER stress (Inagi et al. 2005, Cheng et al. 2006). Moreover, the accumulation of AGEs within the skin (representing tissue accumulation) also predicts those T1D individuals at a greatest risk of developing nephropathy (Yu et al. 2006). Additionally albumin, a major component in the proteinuria observed in $\mathrm{DN}$, is often reflective of progressive disease associated with a declining glomerular filtration barrier and increased leaching into the urine. Not only could excessive exposure of podocytes to albumin induce ER stress pathways leading to caspase-12-mediated podocyte apoptosis independent of mitochondrial input (Chen et al. 2011), but also it appears that the modification of albumin by AGEs enhances pro-apoptotic pathways in podocytes in a dose- and time-dependent manner (Chen et al. 2008). Moreover, Chuang et al. (2007) observed that both soluble and matrix-bound AGEs induced apoptosis in podocytes in an additive manner and they further observed an increase in podocyte detachment when they were cultured in the presence of AGE-modified

Published by Bioscientifica Ltd. 
collagen IV. This is of particular interest as this may implicate not only the number of podocytes as a major determinant in the development and progression of DN but also their integrity, which has been well described (Sachs \& Sonnenberg 2013). Moreover, parallels can be drawn from this postulation, with the identification that the ability for the podocyte to effectively adhere to the extracellular matrix is a major determinant of ER stress induction and the subsequent development of glomerular injury (Cybulsky et al. 2011). This may indicate that with the onset of podocyte dysfunction, ER stress could potentially exacerbate damage to the cell.

Moreover, it is suggested that during the advent of hyperglycaemia in diabetic patients, the balance of the ER load in the podocyte is perturbed through a number of systemic pathways leading to the induction of ER stress and subsequently podocyte injury. Indeed, ER stress is induced in podocytes when acutely stimulated under both highglucose (Cao et al. 2014) and low-glucose (Fujii et al. 2006) conditions, and it is apparent that there are regulatory mechanisms to alleviate this stress when podocytes are chronically exposed to hyperglycaemic conditions (Inagi et al. 2005). Given that cell survival is promoted through the activation of autophagy in the advent of ER stress induced in mammalian cells in a high-glucose environment (Ogata et al. 2006), it is likely that compensatory modifications to the ER could be directly linked to autophagy.

\section{Adaptive responses to a perturbed ER in the diabetic podocyte}

Autophagy, a highly regulated lysosomal pathway, selectively targets and removes damaged organelles and is suspected to further function in tandem with the ER as a compensatory mechanism for proteasomal degradation (Ding et al. 2007). Not only is autophagy implicated to function in the adaptation of stress and survival mechanisms, but also autophagy may play a distinctive role in the metabolic regulation of a cell. It appears that autophagy intricately regulates lipid metabolism (Singh et al. 2009a,b) and is involved in the degradation of large glycogen stores in the hepatocytes of neonates (Kalamidas et al. 2004). Interestingly, podocytes maintain a constitutively higher level of autophagy when compared with other intrinsic renal cells (Asanuma et al. 2003, Hartleben et al. 2010). This may simply be due to the limited capacity for regeneration of the podocyte and hence requirement to constantly recycle and renew cellular components. However, there may be an underlying involvement of autophagy in the metabolic capacity of the podocyte.
Recent developments in the understanding of the function of the protein kinase mammalian target of rapamycin complex 1 (mTORC1) in podocytes have identified a relationship between autophagy and ER function. mTORC1 is a kinase complex involved in a myriad of cellular processes including a modulatory role of autophagy in response to nutrients such as glucose, amino acids and growth factors (Hay \& Sonenberg 2004). Interestingly, there is evidence to suggest that much like mTORC1, the UPR can be activated through various physiological stimuli (circulating FFAs (Pineau \& Ferreira 2010), hypoxia (Wouters \& Koritzinsky 2008) and growth stimuli (Christis et al. 2010, Pfaffenbach et al. 2010)) that do not necessarily act through the accumulation of unfolded proteins in the ER. Moreover, a recent review (AppenzellerHerzog \& Hall 2012) has elaborately summarised how mTORC1 operates both upstream and downstream of ER stress signals, essentially inferring an intricate relationship among ER stress, autophagy and mTORC1. The speculation that mTORC1 may be involved in the pathogenesis of DN came from the observation that an inhibitor of mTORC1 (rapamycin) attenuates renal hypertrophy in experimental models of DN (Sakaguchi et al. 2006). Rapamycin selectively restores integrity of the podocyte foot processes through the stabilisation of the protein nephrin in the filtration barrier and reduces subsequent tubular and glomerular damage (Inoki et al. 2011, Kato et al. 2012). Nephrin is an integral podocyte protein involved in the retention of larger macromolecules in the blood as well as playing a role in the membrane docking of the insulin-sensitive glucose transporter, GLUT4 (Coward et al. 2007). However, the changes to the role and function of mTORC1 in podocytes, in response to the metabolic alterations that occur during diabetes, remain to be completely delineated.

It has been suggested, however, that mTORC1 activation in podocytes may play an essential role in the development of DN, as podocyte-specific mTORC1 activation in the absence of diabetes recapitulated several features of DN (Inoki et al. 2011). Coupled with the chronic activation of mTORC1 in the podocytes, ER stress was enhanced in the glomeruli and the pathological changes in the podocyte could partially be attributed to ER stress (Inoki et al. 2011). When mTORC1 activity was genetically reduced in diabetic mice, there was a significant reduction in the development of DN (Inoki et al. 2011). Consistent with the ideology that the activation of the UPR can occur both downstream and upstream of mTORC1 infers a particularly interesting notion that, in certain contexts, mTORC1 is a component of the process of ER stress-induced cell toxicity, and if perturbed in the

Published by Bioscientifica Ltd. 
podocyte, could be crucial to the development of $\mathrm{DN}$. Indeed, despite the fact that hyper-activation of mTORC1 in mouse podocytes led to a phenotype akin to that of DN, reducing mTORC1 activity similarly promoted podocyte dysfunction (Godel et al. 2011), indicating that mTORC1 activity is essential for the development of the podocyte. Interestingly, Inoki et al. (2011) determined that mTORC1 was causing podocyte dysfunction by retention of nephrin in the cytoplasm, where it could not localise to the renal filtration barrier during hyper-activation of mTORC1 in podocytes. Not only would impairments and the subsequent accumulation of dysfunctional nephrin promote ER stress (Drozdova et al. 2013), but also a decline in nephrin is known to lead to the development of proteinuria (Langham et al. 2002) and glucose homoeostatic defects in podocytes. As mentioned above, a loss of nephrin also impairs GLUT4 trafficking to the plasma membrane and therefore insulin-dependent glucose uptake (Coward et al. 2007). However, the mechanism by which mTORC1 activity alters the capacity of nephrin to localise to the glomerular filtration barrier needs to be further explored. One possible avenue would be to identify the effects of post-translational modifications of nephrin in the ER and Golgi, which could alter nephrin localisation and function. One particular modification of interest is $N$-glycosylation, which plays a critical role in mediating membrane localisation of nephrin (Yan et al. 2002) and occurs within the ER. Hence, impaired protein modification in the ER, either through mechanisms directly or indirectly associated with ER stress, could also promote podocyte dysfunction and hence influence the progression of DN.

These data illustrate a rather intricate relationship between ER stress and mTORC1 activity (Fig. 1). Although there is growing body of evidence indicating the crucial role for the mTORC1 pathway in podocyte health, unfortunately, at present, there is a limited understanding of the intersecting relationship among ER stress, mTOR and the UPR in the development of human DN.

\section{ER stress-mediated tubulointerstitial injury}

Tubulointerstitial damage is considered a final common pathway to end-stage kidney disease, where the deposition of extracellular matrix, oedema and infiltrating cells separate the proximal tubules from their intimate contact with the renal tubular capillaries. As one of the primary functions of the proximal tubule is the reabsorption of substances, such as glucose and sodium, from the urinary filtrate and their return into the bloodstream, tubulointerstitial fibrosis is the best prognostic indicator of progression to end-stage renal disease requiring transplantation or dialysis. However, in patients with diabetes, renal biopsies are no longer performed routinely due to an increased risk of bleeding and poor wound healing within this population. Proximal tubular epithelial cells (PTCs) are another particular type of cells of interest in the pathophysiology of kidney tubular injury in DN (Remuzzi \& Bertani 1998), particularly as they are highly susceptible to ER stressors (Zinszner et al. 1998) and are highly synthetic and metabolically active cells.

\section{Mechanisms culminating a stressed diabetic PTC ER}

A common hallmark of DN is proteinuria, specifically the loss of albumin (albuminuria), and one of the central roles of the PTCs is the ability to reabsorb a proportion of proteins that may be filtered by the glomerulus and consequently end up within the urinary filtrate, which is exacerbated in the context of diabetes. Moreover, several studies show a direct association between proteinuria and pathogenesis of tubular injury, with the levels of albumin and modified albumin as the determinant factor (Ruggenenti et al. 1998, Coughlan et al. 2011). The effects of albumin on PTCs are biphasic, where on one hand albumin stimulates the growth of PTCs (Iglesias et al. 1999, Dixon \& Brunskill 2000) while on the other hand, excessive exposure to albumin is implicated in tubular atrophy in a pro-apoptotic and pro-inflammatory environment (Ohse et al. 2006). Moreover, albumin-induced ER stress is implicated in causing tubular damage through the activation of caspase 12 subsequently resulting in apoptosis of PTCs (Ohse et al. 2006). Excessive reabsorption of albumin has also been suggested to promote reactive oxygen species production and activation of $\operatorname{PPAR} \gamma$, stimulating GRP78 and eIF $2 \alpha$ phosphorylation, both of which are markers of ER stress. ER stress subsequently stimulated downstream phosphorylation of JNK and NFKB, resulting in increased expression of sodium-dependent glucose transporter 2 (SGLT2 (SLC5A2)) in cultured rabbit PTCs (Lee et al. 2009). Increased SGLT2 expression has previously been identified in PTCs isolated from the urine in T2D patients (Rahmoune et al. 2005). However, mice that have the expression of Sglt2 ablated in the PTCs are not protected against the development or progression of kidney injury (Vallon et al. 2013). Whether increased expression of SGLT2 correlates with an increased risk of the development of DN is yet to be determined. Nevertheless, given the important role of SGLT2 in glucose reabsorption in the

Published by Bioscientifica Ltd 
proximal tubule and the advent of new therapies in diabetic treatment regimens that target this protein to control hyperglycaemia by inducing glycosuria (Bailey et al. 2010, Wilding et al. 2012), these pathways involving ER stress warrant further investigation and understanding.

\section{Adaptive responses to a perturbed ER in diabetic PTCs}

What is particularly interesting to note is the identification of mTORC1 as an upstream mediator in PTCs, before the induction of ER stress as a result of excess albumin exposure (Lee et al. 2011), although whether albumin derived from human sera functions in a similar manner is yet to be determined. Similar to podocytes, mTORC1 may also play a crucial role in the pathophysiology of kidney tubular injury through the regulation of ER stress. Interestingly, it has been further elucidated, in tubular cells, that activation of pro-apoptotic pathways can be mediated by the induction of ER stress. Not only was mTORC1 determined to function downstream of ER stress in these cells, but subsequent mTORC1 activity involved pathways culminating in IRE1-JNK activation (Kato et al. 2012). Interestingly, inhibition of mTORC1 with rapamycin under the same physiological conditions selectively inhibited the IRE1 pathway. This further implies mTORC1 activity both upstream and downstream of ER stress; however, the reason that mTORC1 selectively activates the IRE1 branch and not the other branches of the UPR needs to be further elucidated. One interpretation (Fig. 2) suggests that albumin may direct ER stress in the proximal tubules of diabetic patients with albuminuria, mediating reduced insulin responsiveness in the PTCs through IRE1-JNK activation driven by mTORC1, in which the IRE1-JNK pathway has been shown to reduce insulin sensitivity in adipocytes, although mTOR activity was decreased in the adipose tissue of the T2D patients (Li et al. 2014). Reduced mTOR activity could simply be a consequence of developed insulin resistance, as sustained activation of mTORC1 renders insulin receptor signalling pathways irresponsive to insulin (Shah et al. 2004). Ultimately whether mTORC1 activity would reduce insulin sensitivity in PTCs needs to be confirmed. However, the question of how insulin is relevant to the PTCs is an evolving concept, given that these cells are not physiologically insulin-sensitive cells with respect to glucose uptake, nor do they manufacture the enzymes necessary to perform glycolysis under normal conditions (Vallon 2011). Recent research has revealed that indeed PTCs require insulin receptor-mediated signalling for their normal function, and when the insulin receptor was specifically deleted in the PTCs, mice exhibited increased renal gluconeogenesis independent of glucose clearance, as well as enhanced insulin secretion and action (Tiwari et al. 2013). It is postulated that the downregulation of insulin receptor and/or insulin resistance in the PTCs could further contribute to hyperglycaemia, which could effectively enhance the risk for the development of DN. Although the mechanisms and actions of mTORC1 remain to be further explored in these cells, mTORC1 activity may play a central role not only in tubular injury via changes in insulin receptor signalling but also in the development of DN.

\section{Therapeutic implications of ER stress modulators}

Current approaches to treat DN largely target systemic blood pressure and/or intraglomerular hypertension. More often than not the first line of therapies for the treatment of DN are those that influence the reninangiotensin system, including angiotensin-converting enzyme inhibitors (Lewis et al. 1993) and angiotensin II receptor antagonists (Brenner et al. 2001), with concurrent glycaemic control agents and often therapies for hyperlipidaemia. Despite these interventions, progression of DN to end-stage renal disease can only be slowed but not cured. Although these interventions are currently the most effective techniques for clinical management of microvascular complications such as nephropathy, there is also evidence to suggest that strict glycaemic control does not necessarily reduce the risk of cardiovascular disease (Gerstein et al. 2008) and may potentially elevate the risk of a cardiovascular event (Patel et al. 2008). Moreover, an unfortunate phenomenon often observed in the treatment of diabetes and its complications is poor adherence to treatment regimens, particularly with the rates of adherence inversely proportional to the number of diabetic medications prescribed (Cramer 2004). This provides a rationale for the necessity of developing not only novel therapeutics that can target multiple pathways, but also therapeutics that assist in improving patient compliance as well as addressing other pathogenic mediators. A potential avenue to assist in achieving this therapeutic goal may be to target ER stress pathways.

There are a myriad of compounds (Table 1) that improve ER folding capacity such as the chemical chaperones 4-phenylbutyric acid (PBA), taurine-conjugated ursodeoxycholic acid (TUDCA) and ER chaperones that reduce ER stress and improve insulin action and sensitivity (Ozawa et al. 2005, Ozcan et al. 2006). Small-molecule

Published by Bioscientifica Ltd 


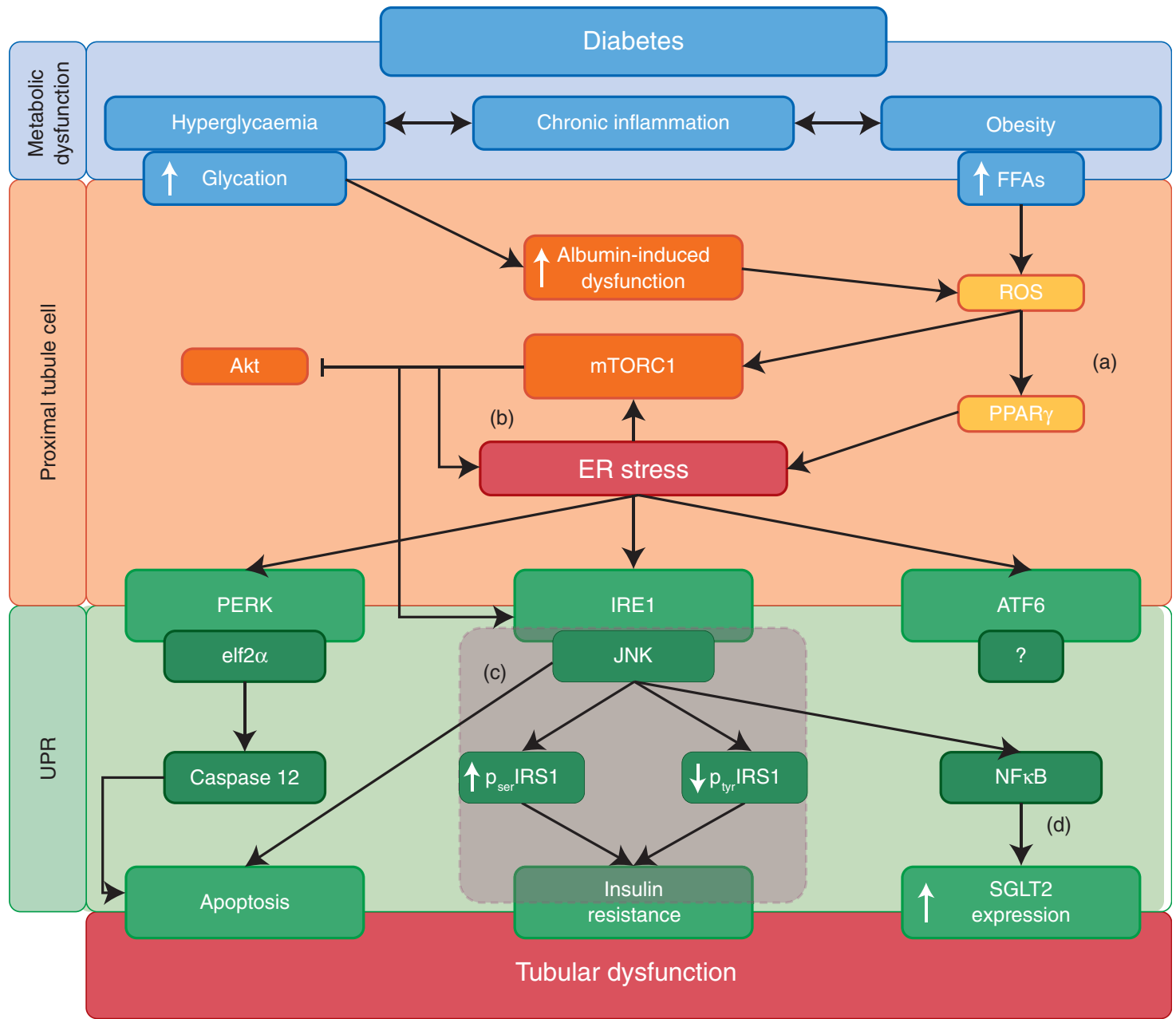

\section{Figure 2}

A summary of the proposed mechanisms of ER stress-induced tubular dysfunction. Metabolic imbalances in diabetes (hyperglycaemia, inflammation and obesity) contribute to the interacting pathways of ER stress contributing to tubular dysfunction. Enhanced glycation is directly associated with pathways implicated in the development of diabetic nephropathy (DN) through the modification of albumin generating large macromolecular complexes (Penfold et al. 2010). (a) Excessive reabsorption of albumin is thought to overload the PTCs leading to ER stress-induced apoptosis mediated by caspase 12 activation (Ohse et al. 2006).

(b) Moreover, albumin appears to have an intricate signalling pathway both upstream and downstream of ER stress mediated by mTORC1.

chemical chaperones such as TUDCA and 4-PBA are suspected to enhance either protein secretion or the folding capacity of the ER (Park \& Ozcan 2013). Indeed, recent work on experimental models of DN has demonstrated that 4-PBA (Qi et al. 2011) and TUDCA (Chen et al. 2008, Fang et al. 2013) could potentially slow the progression of DN through the attenuation of ER stress-induced apoptosis via the reduction of GRP78 and PERK expression, and the restoration of defective autophagy. However, it is not yet understood whether chemical chaperones could directly
Enhanced mTORC1 activity in the PTCs not only contributes to proapoptotic pathways, but through the selective activation of the IRE1-JNK pathway could also lead to decreased responsiveness to insulin in the PTCs. (c) However, it is important to note that the proposed pathway leading to IRE1-JNK-induced insulin resistance was only identified in adipocytes from T2D patients (Li et al. 2014) and has not been substantiated in PTCs.

(d) Furthermore, JNK activation could further promote metabolic imbalances in the PTCs through ER stress-induced NFKB stimulation of SGLT2 expression (Lee et al. 2009). ER stress might perturb the metabolic integrity of the proximal tubule, which could be a crucial pathway contributing to the pathogenesis of DN.

improve kidney function or whether these results are simply confounded by the improvement in glycaemic control observed with this class of agents. Despite a recent clinical investigation determining that oral TUDCA administration can increase both hepatic and muscular insulin sensitivities in obese non-diabetic patients (Kars et al. 2010), markers of ER stress were not improved and therefore it is evident that there is still relatively little known about the long-term efficacy and target specificity of these ER stress modulators in humans.

Published by Bioscientifica Ltd. 
Table 1 ER stress modulators of particular interest

$\begin{array}{ll}\text { ER stress modulator } & \\ \begin{array}{c}\text { 4-Phenyl-butyric } \\ \text { acid (4-PBA) }\end{array} & \text { ER chaperone }\end{array}$
acid (4-PBA)

Taurine-conjugated ER chaperone Podocytes
ursodeoxycholic
acid (TUDCA)

\section{Palmitoleic/oleic} acid

Rapamycin

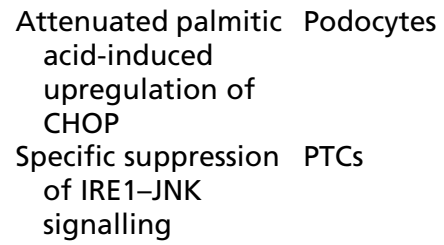

Cells investigated

\section{Disease model \\ STZ-induced diabetes}

Clinical trial: obese non-diabetic

TM-treated mice

Podocytes
PcKOTsc1 mice

\begin{tabular}{l} 
Outcomes \\
\hline Attenuates proteinuria, \\
oxidative stress markers \\
p-JNK, MCP1 and TGF $\beta 1$, \\
ER stress markers GRP78 \\
and PERK \\
Suppressed AGE-induced \\
elevation of GRP78 and \\
dose-dependently \\
inhibited podocyte \\
apoptosis \\
Increased hepatic and \\
muscle insulin sensi- \\
tivities. Markers of ER \\
stress did not change \\
Reduced palmitic \\
acid-induced apoptosis \\
of podocytes \\
Suppressed renal tubular \\
injury \\
Early intervention \\
regenerated podocyte \\
foot processes \\
Reversed mTORC1-depen- \\
dent podocyte injury
\end{tabular}

References

Qi et al. (2011)

Chen et al. (2008)

Kars et al. (2010)

Sieber et al. (2010)

Kato et al. (2012)

Inoki et al. (2011)

STZ, streptozotocin; TM, tunicamycin.

Rapamycin (sirolimus), an mTOR inhibitor, is currently approved by the FDA as an anti-restenotic agent and immunosuppressant. Clinical studies of rapamycin have shown significant efficacy in improving glycaemic control in T1D patients following pancreatic islet transplantation (Shapiro et al. 2000). Moreover, sirolimus-based trials of kidney transplantation also improved acute rejection and minimised nephrotoxicity often observed with other immunomodulators (Kahan et al. 1998, Groth et al. 1999). However, it is difficult to determine if this class of agent or rapamycin-based therapeutics could be beneficial in the treatment of DN. Although results from mouse-based experimental models indicate that a reduction in mTORC1 activity could reduce the development of DN (Inoki et al. 2011). Pharmacological inhibition of the mTOR pathway by rapamycin should be approached cautiously, given the evident off-target effects described with the longstanding application of rapamycin (Sarbassov et al. 2006).

Chemical chaperones that enhance protein folding are not the only avenue for ER modulation. Indeed, agents targeting other pathways such as dietary intervention through the reduction of palmitic acid could reduce ER-stress-mediated CHOP upregulation in podocytes and thereby attenuate pro-apoptotic pathways mediated by ER stress (Sieber et al. 2010). Moreover, antioxidant therapy using $\alpha$-lipoic acid has been determined to reduce hepatic lipid accumulation, ER stress biomarkers and glomerular mesangial matrix expansion (Melhem et al. 2002, Min et al. 2012) in other contexts. There is evidence that increasing consumption of polyunsaturated fatty acids could attenuate DN both in animal models and in humans (Shapiro et al. 2011), although it remains to be determined as to whether this is modulated through improvement in ER stability. These results indicate that perhaps dietary intervention involving a shift to increased unsaturated FFAs and reduced saturated fats could reduce ER-stress-related renal cellular toxicity, particularly in T2D where lipid accumulation plays a more integral role in disease pathology.

\section{Concluding remarks}

Whether or not ER stress directly contributes to the pathogenesis of nephropathy in the context of diabetes is still an unanswered question, but it is apparent that there is ER stress within specific renal cells. Furthermore, there are certainly lessons to be learnt from other sites within the body, as it is evident that ER stress is not a uniform phenomenon, particularly affecting highly synthetic sites.

Published by Bioscientifica Ltd. 
Hence, drawing similarities between seemingly disparate sites which commonly present with ER stress in disease states may assist us to further understand this mystery. However, whether or not ER stress plays a causative role in the pathogenesis of $\mathrm{DN}$ is not yet defined, nor is the regulatory role of the UPR in highly synthetic organs such as the kidney well understood. Certainly, using modulators of ER function and stress in experimental models of DN may provide some answers in this context. However, the ability of these modulators to specifically target the renal cells of interest and their mechanism of action need to be further explored particularly given the complexity of the kidney, which contains more than eight resident cell types. There should also be an emphasis placed on the investigation of societal and psychological implications as to how to best integrate these novel therapeutics in conjunction with proven treatment regimens to assist in improving government regulatory authorities, patient compliance and ultimately patient health and well-being.

\section{Declaration of interest}

The authors declare that there is no conflict of interest that could be perceived as prejudicing the impartiality of the review.

\section{Funding}

A Zhuang was supported by a Biomedical Research scholarship provided by Kidney Health Australia (grant number SCH17 141516) and J M Forbes was supported by a National Medical Research Council of Australia Senior Researcher Fellowship (grant number APP1004503).

\section{Acknowledgements}

The authors indicate that there are no acknowledgements required to be made.

\section{References}

Allotey RA, Mohan V, McDermott MF, Deepa R, Premalatha G, Hassan Z, Cassell PG, North BV, Vaxillaire M, Mein CA et al. 2004 The EIF2AK3 gene region and type I diabetes in subjects from South India. Genes and Immunity 5 648-652. (doi:10.1038/sj.gene.6364139)

Appenzeller-Herzog C \& Hall MN 2012 Bidirectional crosstalk between endoplasmic reticulum stress and mTOR signaling. Trends in Cell Biology 22 274-282. (doi:10.1016/j.tcb.2012.02.006)

Araki K \& Nagata K 2011 Protein folding and quality control in the ER. Cold Spring Harbor Perspectives in Biology 3 a007526. (doi:10.1101/ cshperspect.a007526)

Asanuma K, Tanida I, Shirato I, Ueno T, Takahara H, Nishitani T, Kominami E \& Tomino Y 2003 MAP-LC3, a promising autophagosomal marker, is processed during the differentiation and recovery of podocytes from PAN nephrosis. FASEB Journal 17 1165-1167. (doi:10.1096/fj.02-0580fje)

Bailey CJ, Gross JL, Pieters A, Bastien A \& List JF 2010 Effect of dapagliflozin in patients with type 2 diabetes who have inadequate glycaemic control with metformin: a randomised, double-blind, placebocontrolled trial. Lancet 375 2223-2233. (doi:10.1016/S01406736(10)60407-2)

Beriault DR \& Werstuck GH 2012 The role of glucosamine-induced ER stress in diabetic atherogenesis. Experimental Diabetes Research 2012187018. (doi:10.1155/2012/187018)

Boden G, Duan X, Homko C, Molina EJ, Song W, Perez O, Cheung P \& Merali S 2008 Increase in endoplasmic reticulum stress-related proteins and genes in adipose tissue of obese, insulin-resistant individuals. Diabetes 57 2438-2444. (doi:10.2337/db08-0604)

Brenner BM, Cooper ME, de Zeeuw D, Keane WF, Mitch WE, Parving HH, Remuzzi G, Snapinn SM, Zhang Z \& Shahinfar S 2001 Effects of losartan on renal and cardiovascular outcomes in patients with type 2 diabetes and nephropathy. New England Journal of Medicine 345 861-869. (doi:10.1056/NEJMoa011161)

Cao Y, Hao Y, Li H, Liu Q, Gao F, Liu W \& Duan H 2014 Role of endoplasmic reticulum stress in apoptosis of differentiated mouse podocytes induced by high glucose. International Journal of Molecular Medicine 33 809-816. (doi:10.3892/ijmm.2014.1642)

Chandie Shaw PK, Baboe F, van Es LA, van der Vijver JC, van de Ree MA, de Jonge N \& Rabelink TJ 2006 South-Asian type 2 diabetic patients have higher incidence and faster progression of renal disease compared with Dutch-European diabetic patients. Diabetes Care 29 1383-1385. (doi:10.2337/dc06-0003)

Chen Y, Liu CP, Xu KF, Mao XD, Lu YB, Fang L, Yang JW \& Liu C 2008 Effect of taurine-conjugated ursodeoxycholic acid on endoplasmic reticulum stress and apoptosis induced by advanced glycation end products in cultured mouse podocytes. American Journal of Nephrology $\mathbf{2 8}$ 1014-1022. (doi:10.1159/000148209)

Chen S, He FF, Wang H, Fang Z, Shao N, Tian XJ, Liu JS, Zhu ZH, Wang YM, Wang $S$ et al. 2011 Calcium entry via TRPC6 mediates albumin overload-induced endoplasmic reticulum stress and apoptosis in podocytes. Cell Calcium 50 523-529. (doi:10.1016/j.ceca.2011.08.008)

Cheng DW, Jiang Y, Shalev A, Kowluru R, Crook ED \& Singh LP 2006 An analysis of high glucose and glucosamine-induced gene expression and oxidative stress in renal mesangial cells. Archives of Physiology and Biochemistry 112 189-218. (doi:10.1080/13813450601093518)

Christis C, Fullaondo A, Schildknegt D, Mkrtchian S, Heck AJ \& Braakman I 2010 Regulated increase in folding capacity prevents unfolded protein stress in the ER. Journal of Cell Science $\mathbf{1 2 3}$ 787-794. (doi:10.1242/ jcs.041111)

Chu WS, Das SK, Wang H, Chan JC, Deloukas P, Froguel P, Baier LJ, Jia W, McCarthy MI, Ng MC et al. 2007 Activating transcription factor 6 (ATF6) sequence polymorphisms in type 2 diabetes and pre-diabetic traits. Diabetes 56 856-862. (doi:10.2337/db06-1305)

Chuang PY, Yu Q, Fang W, Uribarri J \& He JC 2007 Advanced glycation endproducts induce podocyte apoptosis by activation of the FOXO4 transcription factor. Kidney International 72 965-976. (doi:10.1038/ sj.ki.5002456)

Collins R, Armitage J, Parish S, Sleigh P \& Peto R 2003 MRC/BHF Heart Protection Study of cholesterol-lowering with simvastatin in 5963 people with diabetes: a randomised placebo-controlled trial. Lancet 361 2005-2016. (doi:10.1016/S0140-6736(03)12475-0)

Coughlan MT, Patel SK, Jerums G, Penfold SA, Nguyen TV, Sourris KC, Panagiotopoulos S, Srivastava PM, Cooper ME, Burrell LM et al. 2011 Advanced glycation urinary protein-bound biomarkers and severity of diabetic nephropathy in man. American Journal of Nephrology 34 347-355. (doi:10.1159/000331064)

Coward RJ, Welsh GI, Yang J, Tasman C, Lennon R, Koziell A, Satchell S, Holman GD, Kerjaschki D, Tavare JM et al. 2005 The human glomerular podocyte is a novel target for insulin action. Diabetes $\mathbf{5 4} 3095-3102$. (doi:10.2337/diabetes.54.11.3095)

Coward RJ, Welsh GI, Koziell A, Hussain S, Lennon R, Ni L, Tavare JM, Mathieson PW \& Saleem MA 2007 Nephrin is critical for the action of insulin on human glomerular podocytes. Diabetes 56 1127-1135. (doi:10.2337/db06-0693) http://joe.endocrinology-journals.org DOI: 10.1530/JOE-13-0517
(C) 2014 Society for Endocrinology Printed in Great Britain 
Cox JS, Shamu CE \& Walter P 1993 Transcriptional induction of genes encoding endoplasmic reticulum resident proteins requires a transmembrane protein kinase. Cell 73 1197-1206. (doi:10.1016/ 0092-8674(93)90648-A)

Cramer JA 2004 A systematic review of adherence with medications for diabetes. Diabetes Care 27 1218-1224. (doi:10.2337/diacare.27.5.1218)

Cybulsky AV, Takano T, Papillon J, Kitzler TM \& Bijian K 2011 Endoplasmic reticulum stress in glomerular epithelial cell injury. American Journal of Physiology. Renal Physiology 301 F496-F508. (doi:10.1152/ajprenal. 00728.2010)

Cylwik B, Naklicki M, Chrostek L \& Gruszewska E 2013 Congenital disorders of glycosylation. Part I. Defects of protein $\mathrm{N}$-glycosylation. Acta Biochimica Polonica 60 151-161.

Dickhout JG \& Krepinsky JC 2009 Endoplasmic reticulum stress and renal disease. Antioxidants \& Redox Signaling 11 2341-2352. (doi:10.1089/ ars.2009.2705)

Ding WX, Ni HM, Gao W, Yoshimori T, Stolz DB, Ron D \& Yin XM 2007 Linking of autophagy to ubiquitin-proteasome system is important for the regulation of endoplasmic reticulum stress and cell viability. American Journal of Pathology 171 513-524. (doi:10.2353/ajpath.2007. 070188)

Dixon R \& Brunskill NJ 2000 Albumin stimulates p44/p42 extracellularsignal-regulated mitogen-activated protein kinase in opossum kidney proximal tubular cells. Clinical Science 98 295-301. (doi:10.1042/ CS19990214)

Dobson CM 2003 Protein folding and misfolding. Nature 426 884-890. (doi:10.1038/nature02261)

Drozdova T, Papillon J \& Cybulsky AV 2013 Nephrin missense mutations: induction of endoplasmic reticulum stress and cell surface rescue by reduction in chaperone interactions. Physiological Reports 1 e00086. (doi:10.1002/phy2.86)

Fang L, Zhou Y, Cao H, Wen P, Jiang L, He W, Dai C \& Yang J 2013 Autophagy attenuates diabetic glomerular damage through protection of hyperglycemia-induced podocyte injury. PLOS ONE 8 e60546. (doi:10.1371/journal.pone.0060546)

Forbes JM, Cooper ME, Oldfield MD \& Thomas MC 2003 Role of advanced glycation end products in diabetic nephropathy. Journal of the American Society of Nephrology 14 S254-S258. (doi:10.1097/01.ASN.0000077413. 41276.17)

Fried LF, Orchard TJ \& Kasiske BL 2001 Effect of lipid reduction on the progression of renal disease: a meta-analysis. Kidney International 59 260-269. (doi:10.1046/j.1523-1755.2001.00487.x)

Fujii Y, Khoshnoodi J, Takenaka H, Hosoyamada M, Nakajo A, Bessho F, Kudo A, Takahashi S, Arimura Y, Yamada A et al. 2006 The effect of dexamethasone on defective nephrin transport caused by ER stress: a potential mechanism for the therapeutic action of glucocorticoids in the acquired glomerular diseases. Kidney International 69 1350-1359. (doi:10.1038/sj.ki.5000317)

Gao Y, Sartori DJ, Li C, Yu QC, Kushner JA, Simon MC \& Diehl JA 2012 PERK is required in the adult pancreas and is essential for maintenance of glucose homeostasis. Molecular and Cellular Biology 32 5129-5139. (doi:10.1128/MCB.01009-12)

Gerstein HC, Miller ME, Byington RP, Goff DC Jr, Bigger JT, Buse JB, Cushman WC, Genuth S, Ismail-Beigi F, Grimm RH Jr et al. 2008 Effects of intensive glucose lowering in type 2 diabetes. New England Journal of Medicine 358 2545-2559. (doi:10.1056/NEJMoa0802743)

Glimcher LH 2010 XBP1: the last two decades. Annals of the Rheumatic Diseases 69(Suppl 1) i67-i71. (doi:10.1136/ard.2009.119388)

Godel M, Hartleben B, Herbach N, Liu S, Zschiedrich S, Lu S, Debreczeni-Mor A, Lindenmeyer MT, Rastaldi MP, Hartleben G et al. 2011 Role of mTOR in podocyte function and diabetic nephropathy in humans and mice. Journal of Clinical Investigation 121 2197-2209. (doi:10.1172/JCI44774)

Goldspink DF \& Kelly FJ 1984 Protein turnover and growth in the whole body, liver and kidney of the rat from the foetus to senility. Biochemical Journal 217 507-516.
Gregor MF, Yang L, Fabbrini E, Mohammed BS, Eagon JC, Hotamisligil GS \& Klein S 2009 Endoplasmic reticulum stress is reduced in tissues of obese subjects after weight loss. Diabetes 58 693-700. (doi:10.2337) db08-1220)

Gross JL, Zelmanovitz T, Moulin CC, De Mello V, Perassolo M, Leitao C, Hoefel A, Paggi A \& Azevedo MJ 2002 Effect of a chicken-based diet on renal function and lipid profile in patients with type 2 diabetes: a randomized crossover trial. Diabetes Care 25 645-651. (doi:10.2337/ diacare.25.4.645)

Groth CG, Backman L, Morales JM, Calne R, Kreis H, Lang P, Touraine JL, Claesson K, Campistol JM, Durand D et al. 1999 Sirolimus (rapamycin)based therapy in human renal transplantation: similar efficacy and different toxicity compared with cyclosporine. Sirolimus European Renal Transplant Study Group. Transplantation 67 1036-1042. (doi:10.1097/00007890-199904150-00017)

Harding HP, Zhang Y \& Ron D 1999 Protein translation and folding are coupled by an endoplasmic-reticulum-resident kinase. Nature $\mathbf{3 9 7}$ 271-274. (doi:10.1038/16729)

Harding HP, Zeng H, Zhang Y, Jungries R, Chung P, Plesken H, Sabatini DD \& Ron D 2001 Diabetes mellitus and exocrine pancreatic dysfunction in Perk- / - mice reveals a role for translational control in secretory cell survival. Molecular Cell 7 1153-1163. (doi:10.1016/S10972765(01)00264-7)

Hartleben B, Godel M, Meyer-Schwesinger C, Liu S, Ulrich T, Kobler S, Wiech T, Grahammer F, Arnold SJ, Lindenmeyer MT et al. 2010 Autophagy influences glomerular disease susceptibility and maintains podocyte homeostasis in aging mice. Journal of Clinical Investigation 120 1084-1096. (doi:10.1172/JCI39492)

Hasnain SZ, Lourie R, Das I, Chen AC \& McGuckin MA 2012 The interplay between endoplasmic reticulum stress and inflammation. Immunology and Cell Biology 90 260-270. (doi:10.1038/icb.2011.112)

Hay N \& Sonenberg N 2004 Upstream and downstream of mTOR. Genes and Development 18 1926-1945. (doi:10.1101/gad.1212704)

Haze K, Yoshida H, Yanagi H, Yura T \& Mori K 1999 Mammalian transcription factor ATF6 is synthesized as a transmembrane protein and activated by proteolysis in response to endoplasmic reticulum stress. Molecular Biology of the Cell 10 3787-3799. (doi:10.1091/mbc. 10.11.3787)

Hetz C 2012 The unfolded protein response: controlling cell fate decisions under ER stress and beyond. Nature Reviews. Molecular Cell Biology 13 89-102. (doi:10.1038/nrm3270)

Hollien J \& Weissman JS 2006 Decay of endoplasmic reticulum-localized mRNAs during the unfolded protein response. Science 313 104-107. (doi:10.1126/science.1129631)

Hoy W, Kelly A, Jacups S, McKendry K, Baker P, MacDonald S, Wang Z, Punguatji N, Kerinauia J, Tipiloura E et al. 1999 Stemming the tide: reducing cardiovascular disease and renal failure in Australian Aborigines. Australian and New Zealand Journal of Medicine 29 480-483. (doi:10.1111/j.1445-5994.1999.tb00746.x)

Hu C, Zhang R, Wang C, Ma X, Wang J, Bao Y, Xiang K \& Jia W 2011 Lack of association between genetic polymorphisms within DUSP12 - ATF6 locus and glucose metabolism related traits in a Chinese population. BMC Medical Genetics 12 3. (doi:10.1186/1471-2350-12-3)

Iglesias J, Abernethy VE, Wang Z, Lieberthal W, Koh JS \& Levine JS 1999 Albumin is a major serum survival factor for renal tubular cells and macrophages through scavenging of ROS. American Journal of Physiology 277 F711-F722.

Inagi R, Nangaku M, Onogi H, Ueyama H, Kitao Y, Nakazato K, Ogawa S, Kurokawa K, Couser WG \& Miyata T 2005 Involvement of endoplasmic reticulum (ER) stress in podocyte injury induced by excessive protein accumulation. Kidney International 68 2639-2650. (doi:10.1111/ j.1523-1755.2005.00736.x)

Inoki K, Mori H, Wang J, Suzuki T, Hong S, Yoshida S, Blattner SM, Ikenoue T, Ruegg MA, Hall MN et al. 2011 mTORC1 activation in podocytes is a critical step in the development of diabetic nephropathy in mice. Journal of Clinical Investigation 121 2181-2196. (doi:10.1172/JCI44771) 
Iyer S, Korada M, Rainbow L, Kirk J, Brown RM, Shaw N \& Barrett TG 2004 Wolcott-Rallison syndrome: a clinical and genetic study of three children, novel mutation in EIF2AK3 and a review of the literature. Acta Paediatrica 93 1195-1201. (doi:10.1111/j.1651-2227.2004.tb02748.x)

Jing G, Wang JJ \& Zhang SX 2012 ER stress and apoptosis: a new mechanism for retinal cell death. Experimental Diabetes Research 2012 589589. (doi:10.1155/2012/589589)

Kahan BD, Podbielski J, Napoli KL, Katz SM, Meier-Kriesche HU \& Van Buren CT 1998 Immunosuppressive effects and safety of a sirolimus/ cyclosporine combination regimen for renal transplantation. Transplantation 66 1040-1046. (doi:10.1097/00007890-199810270-00013)

Kalamidas SA, Kondomerkos DJ, Kotoulas OB \& Hann AC 2004 Electron microscopic and biochemical study of the effects of rapamycin on glycogen autophagy in the newborn rat liver. Microscopy Research and Technique 63 215-219. (doi:10.1002/jemt.20032)

Kars M, Yang L, Gregor MF, Mohammed BS, Pietka TA, Finck BN, Patterson BW, Horton JD, Mittendorfer B, Hotamisligil GS et al. 2010 Tauroursodeoxycholic acid may improve liver and muscle but not adipose tissue insulin sensitivity in obese men and women. Diabetes 59 1899-1905. (doi:10.2337/db10-0308)

Kato H, Nakajima S, Saito Y, Takahashi S, Katoh R \& Kitamura M 2012 mTORC1 serves ER stress-triggered apoptosis via selective activation of the IRE1-JNK pathway. Cell Death and Differentiation 19 310-320. (doi:10.1038/cdd.2011.98)

Kaufman RJ, Scheuner D, Schroder M, Shen X, Lee K, Liu CY \& Arnold SM 2002 The unfolded protein response in nutrient sensing and differentiation. Nature Reviews. Molecular Cell Biology 3 411-421. (doi:10.1038/nrm829)

Langham RG, Kelly DJ, Cox AJ, Thomson NM, Holthofer H, Zaoui P, Pinel N, Cordonnier DJ \& Gilbert RE 2002 Proteinuria and the expression of the podocyte slit diaphragm protein, nephrin, in diabetic nephropathy: effects of angiotensin converting enzyme inhibition. Diabetologia 45 1572-1576. (doi:10.1007/s00125-002-0946-y)

Lee YJ, Suh HN \& Han HJ 2009 Effect of BSA-induced ER stress on SGLT protein expression levels and $\alpha$-MG uptake in renal proximal tubule cells. American Journal of Physiology. Renal Physiology 296 F1405-F1416. (doi:10.1152/ajprenal.90652.2008)

Lee JY, Chang JW, Yang WS, Kim SB, Park SK, Park JS \& Lee SK 2011 Albumin-induced epithelial-mesenchymal transition and ER stress are regulated through a common ROS-c-Src kinase-mTOR pathway: effect of imatinib mesylate. American Journal of Physiology. Renal Physiology 300 F1214-F1222. (doi:10.1152/ajprenal.00710.2010)

Lemley KV 2003 A basis for accelerated progression of diabetic nephropathy in Pima Indians. Kidney International 63(Suppl 83) S38-S42. (doi:10.1046/j.1523-1755.63.s83.9.x)

Lewis EJ, Hunsicker LG, Bain RP \& Rohde RD 1993 The effect of angiotensin-converting-enzyme inhibition on diabetic nephropathy. The Collaborative Study Group. New England Journal of Medicine 329 1456-1462. (doi:10.1056/NEJM199311113292004)

Li H, Zhou B, Xu L, Liu J, Zang W, Wu S \& Sun H 2014 The reciprocal interaction between autophagic dysfunction and ER stress in adipose insulin resistance. Cell Cycle 13 565-579. (doi:10.4161/cc.27406)

Lindenmeyer MT, Rastaldi MP, Ikehata M, Neusser MA, Kretzler M, Cohen CD \& Schlondorff D 2008 Proteinuria and hyperglycemia induce endoplasmic reticulum stress. Journal of the American Society of Nephrology 19 2225-2236. (doi:10.1681/ASN.2007121313)

Liu G, Sun Y, Li Z, Song T, Wang H, Zhang Y \& Ge Z 2008 Apoptosis induced by endoplasmic reticulum stress involved in diabetic kidney disease. Biochemical and Biophysical Research Communications 370 651-656. (doi:10.1016/j.bbrc.2008.04.031)

van Lummel M, Zaldumbide A \& Roep BO 2013 Changing faces, unmasking the $\beta$-cell: post-translational modification of antigens in type 1 diabetes. Current Opinion in Endocrinology, Diabetes, and Obesity 20 299-306. (doi:10.1097/MED.0b013e3283631417)

Marhfour I, Lopez XM, Lefkaditis D, Salmon I, Allagnat F, Richardson SJ, Morgan NG \& Eizirik DL 2012 Expression of endoplasmic reticulum

http://joe.endocrinology-journals.org DOI: $10.1530 / J O E-13-0517$
(C) 2014 Society for Endocrinology Printed in Great Britain stress markers in the islets of patients with type 1 diabetes. Diabetologia 55 2417-2420. (doi:10.1007/s00125-012-2604-3)

McDonald SP \& Russ GR 2003 Burden of end-stage renal disease among indigenous peoples in Australia and New Zealand. Kidney International 63(Suppl 83) S123-S127. (doi:10.1046/j.1523-1755.63.s83.26.x)

Meex SJ, van Greevenbroek MM, Ayoubi TA, Vlietinck R, van VlietOstaptchouk JV, Hofker MH, Vermeulen VM, Schalkwijk CG, Feskens EJ, Boer JM et al. 2007 Activating transcription factor 6 polymorphisms and haplotypes are associated with impaired glucose homeostasis and type 2 diabetes in Dutch Caucasians. Journal of Clinical Endocrinology and Metabolism 92 2720-2725. (doi:10.1210/jc.2006-2280)

Melhem MF, Craven PA, Liachenko J \& DeRubertis FR $2002 \alpha$-Lipoic acid attenuates hyperglycemia and prevents glomerular mesangial matrix expansion in diabetes. Journal of the American Society of Nephrology $\mathbf{1 3}$ 108-116.

Min AK, Kim MK, Kim HS, Seo HY, Lee KU, Kim JG, Park KG \& Lee IK 2012 $\alpha$-Lipoic acid attenuates methionine choline deficient diet-induced steatohepatitis in C57BL/6 mice. Life Sciences 90 200-205. (doi:10.1016/ j.lfs.2011.11.012)

Mori K, Ma W, Gething MJ \& Sambrook J 1993 A transmembrane protein with a cdc $2^{+} / \mathrm{CDC} 28$-related kinase activity is required for signaling from the ER to the nucleus. Cell 74 743-756. (doi:10.1016/ 0092-8674(93)90521-Q)

Nelson RG, Bennett PH, Beck GJ, Tan M, Knowler WC, Mitch WE, Hirschman GH \& Myers BD 1996 Development and progression of renal disease in Pima Indians with non-insulin-dependent diabetes mellitus. Diabetic Renal Disease Study Group. New England Journal of Medicine 335 1636-1642. (doi:10.1056/NEJM199611283352203)

Ogata M, Hino S, Saito A, Morikawa K, Kondo S, Kanemoto S, Murakami T, Taniguchi M, Tanii I, Yoshinaga K et al. 2006 Autophagy is activated for cell survival after endoplasmic reticulum stress. Molecular and Cellular Biology 26 9220-9231. (doi:10.1128/MCB.01453-06)

Ohse T, Inagi R, Tanaka T, Ota T, Miyata T, Kojima I, Ingelfinger JR, Ogawa S, Fujita T \& Nangaku M 2006 Albumin induces endoplasmic reticulum stress and apoptosis in renal proximal tubular cells. Kidney International 70 1447-1455. (doi:10.1038/sj.ki.5001704)

Oshitari T, Hata N \& Yamamoto S 2008 Endoplasmic reticulum stress and diabetic retinopathy. Vascular Health and Risk Management 4 115-122. (doi:10.2147/vhrm.2008.04.01.115)

Ozawa K, Miyazaki M, Matsuhisa M, Takano K, Nakatani Y, Hatazaki M, Tamatani T, Yamagata K, Miyagawa J, Kitao Y et al. 2005 The endoplasmic reticulum chaperone improves insulin resistance in type 2 diabetes. Diabetes 54 657-663. (doi:10.2337/diabetes.54.3.657)

Ozcan U, Cao Q, Yilmaz E, Lee AH, Iwakoshi NN, Ozdelen E, Tuncman G, Gorgun C, Glimcher LH \& Hotamisligil GS 2004 Endoplasmic reticulum stress links obesity, insulin action, and type 2 diabetes. Science 306 457-461. (doi:10.1126/science.1103160)

Ozcan U, Yilmaz E, Ozcan L, Furuhashi M, Vaillancourt E, Smith RO, Gorgun CZ \& Hotamisligil GS 2006 Chemical chaperones reduce ER stress and restore glucose homeostasis in a mouse model of type 2 diabetes. Science 313 1137-1140. (doi:10.1126/science.1128294)

Pagtalunan ME, Miller PL, Jumping-Eagle S, Nelson RG, Myers BD, Rennke HG, Coplon NS, Sun L \& Meyer TW 1997 Podocyte loss and progressive glomerular injury in type II diabetes. Journal of Clinical Investigation 99 342-348. (doi:10.1172/JCI119163)

Papa FR, Zhang C, Shokat K \& Walter P 2003 Bypassing a kinase activity with an ATP-competitive drug. Science 302 1533-1537. (doi:10.1126/ science.1090031)

Park SW \& Ozcan U 2013 Potential for therapeutic manipulation of the UPR in disease. Seminars in Immunopathology 35 351-373. (doi:10.1007/ s00281-013-0370-z)

Patel A, MacMahon S, Chalmers J, Neal B, Billot L, Woodward M, Marre M, Cooper M, Glasziou P, Grobbee D et al. 2008 Intensive blood glucose control and vascular outcomes in patients with type 2 diabetes. New England Journal of Medicine 358 2560-2572. (doi:10.1056/ NEJMicm066227) 
Penfold SA, Coughlan MT, Patel SK, Srivastava PM, Sourris KC, Steer D, Webster DE, Thomas MC, MacIsaac RJ, Jerums G et al. 2010 Circulating high-molecular-weight RAGE ligands activate pathways implicated in the development of diabetic nephropathy. Kidney International $\mathbf{7 8}$ 287-295. (doi:10.1038/ki.2010.134)

Pfaffenbach KT, Nivala AM, Reese L, Ellis F, Wang D, Wei Y \& Pagliassotti MJ 2010 Rapamycin inhibits postprandial-mediated X-box-binding protein-1 splicing in rat liver. Journal of Nutrition 140 879-884. (doi:10.3945/jn.109.119883)

Pineau L \& Ferreira T 2010 Lipid-induced ER stress in yeast and $\beta$ cells: parallel trails to a common fate. FEMS Yeast Research 10 1035-1045. (doi:10.1111/j.1567-1364.2010.00674.x)

Qi W, Mu J, Luo ZF, Zeng W, Guo YH, Pang Q, Ye ZL, Liu L, Yuan FH \& Feng B 2011 Attenuation of diabetic nephropathy in diabetes rats induced by streptozotocin by regulating the endoplasmic reticulum stress inflammatory response. Metabolism 60 594-603. (doi:10.1016/j.metabol. 2010.07.021)

Rahmoune H, Thompson PW, Ward JM, Smith CD, Hong G \& Brown J 2005 Glucose transporters in human renal proximal tubular cells isolated from the urine of patients with non-insulin-dependent diabetes. Diabetes 54 3427-3434. (doi:10.2337/diabetes.54.12.3427)

Rajapurkar MM, John GT, Kirpalani AL, Abraham G, Agarwal SK, Almeida AF, Gang S, Gupta A, Modi G, Pahari D et al. 2012 What do we know about chronic kidney disease in India: first report of the Indian CKD registry. BMC Nephrology 13 10. (doi:10.1186/1471-2369-13-10)

Remuzzi G \& Bertani T 1998 Pathophysiology of progressive nephropathies. New England Journal of Medicine 339 1448-1456. (doi:10.1056/ NEJM199811123392007)

Ron D \& Walter P 2007 Signal integration in the endoplasmic reticulum unfolded protein response. Nature Reviews. Molecular Cell Biology $\mathbf{8}$ 519-529. (doi:10.1038/nrm2199)

Ros E, Nunez I, Perez-Heras A, Serra M, Gilabert R, Casals E \& Deulofeu R 2004 A walnut diet improves endothelial function in hypercholesterolemic subjects: a randomized crossover trial. Circulation 109 1609-1614. (doi:10.1161/01.CIR.0000124477.91474.FF)

Ruggenenti P, Perna A, Mosconi L, Pisoni R \& Remuzzi G 1998 Urinary protein excretion rate is the best independent predictor of ESRF in non-diabetic proteinuric chronic nephropathies. 'Gruppo Italiano di Studi Epidemiologici in Nefrologia' (GISEN). Kidney International 53 1209-1216. (doi:10.1046/j.1523-1755.1998.00874.x)

Rutkowski DT \& Hegde RS 2010 Regulation of basal cellular physiology by the homeostatic unfolded protein response. Journal of Cell Biology 189 783-794. (doi:10.1083/jcb.201003138)

Sachs N \& Sonnenberg A 2013 Cell-matrix adhesion of podocytes in physiology and disease. Nature Reviews. Nephrology 9 200-210. (doi:10.1038/nrneph.2012.291)

Sakaguchi M, Isono M, Isshiki K, Sugimoto T, Koya D \& Kashiwagi A 2006 Inhibition of mTOR signaling with rapamycin attenuates renal hypertrophy in the early diabetic mice. Biochemical and Biophysical Research Communications 340 296-301. (doi:10.1016/j.bbrc.2005.12.012)

Samanta A, Burden AC, Feehally J \& Walls J 1986 Diabetic renal disease: differences between Asian and white patients. BMJ 293 366-367. (doi:10.1136/bmj.293.6543.366-a)

Sarbassov DD, Ali SM, Sengupta S, Sheen JH, Hsu PP, Bagley AF, Markhard AL \& Sabatini DM 2006 Prolonged rapamycin treatment inhibits mTORC2 assembly and Akt/PKB. Molecular Cell 22 159-168. (doi:10.1016/j.molcel.2006.03.029)

Scheuner D, Song B, McEwen E, Liu C, Laybutt R, Gillespie P, Saunders T, Bonner-Weir S \& Kaufman RJ 2001 Translational control is required for the unfolded protein response and in vivo glucose homeostasis. Molecular Cell 7 1165-1176. (doi:10.1016/S1097-2765(01)00265-9)

Scheuner D, Vander Mierde D, Song B, Flamez D, Creemers JW, Tsukamoto K, Ribick M, Schuit FC \& Kaufman RJ 2005 Control of mRNA translation preserves endoplasmic reticulum function in $\beta$ cells and maintains glucose homeostasis. Nature Medicine 11 757-764. (doi:10.1038/nm1259)

http://joe.endocrinology-journals.org DOI: $10.1530 /$ JOE-13-0517
(C) 2014 Society for Endocrinology Printed in Great Britain
Shah OJ, Wang Z \& Hunter T 2004 Inappropriate activation of the TSC/Rheb/mTOR/S6K cassette induces IRS1/2 depletion, insulin resistance, and cell survival deficiencies. Current Biology 14 1650-1656. (doi:10.1016/j.cub.2004.08.026)

Shapiro AM, Lakey JR, Ryan EA, Korbutt GS, Toth E, Warnock GL, Kneteman NM \& Rajotte RV 2000 Islet transplantation in seven patients with type 1 diabetes mellitus using a glucocorticoid-free immunosuppressive regimen. New England Journal of Medicine $\mathbf{3 4 3}$ 230-238. (doi:10.1056/NEJM200007273430401)

Shapiro H, Theilla M, Attal-Singer J \& Singer P 2011 Effects of polyunsaturated fatty acid consumption in diabetic nephropathy. Nature Reviews. Nephrology 7 110-121. (doi:10.1038/nrneph.2010.156)

Sieber J, Lindenmeyer MT, Kampe K, Campbell KN, Cohen CD, Hopfer H, Mundel P \& Jehle AW 2010 Regulation of podocyte survival and endoplasmic reticulum stress by fatty acids. American Journal of Physiology. Renal Physiology 299 F821-F829. (doi:10.1152/ajprenal. 00196.2010)

Singh R, Kaushik S, Wang Y, Xiang Y, Novak I, Komatsu M, Tanaka K, Cuervo AM \& Czaja MJ 2009a Autophagy regulates lipid metabolism. Nature 458 1131-1135. (doi:10.1038/nature07976)

Singh R, Xiang Y, Wang Y, Baikati K, Cuervo AM, Luu YK, Tang Y, Pessin JE, Schwartz GJ \& Czaja MJ 2009b Autophagy regulates adipose mass and differentiation in mice. Journal of Clinical Investigation 119 3329-3339. (doi:10.1172/JCI35541)

Skog O, Korsgren S, Melhus A \& Korsgren O 2013 Revisiting the notion of type 1 diabetes being a T-cell-mediated autoimmune disease. Current Opinion in Endocrinology, Diabetes, and Obesity 20 118-123. (doi:10.1097/MED.0b013e32835edb89)

Susztak K, Raff AC, Schiffer M \& Bottinger EP 2006 Glucose-induced reactive oxygen species cause apoptosis of podocytes and podocyte depletion at the onset of diabetic nephropathy. Diabetes 55 225-233. (doi:10.2337/diabetes.55.01.06.db05-0894)

Tan AL, Sourris KC, Harcourt BE, Thallas-Bonke V, Penfold S, Andrikopoulos S, Thomas MC, O'Brien RC, Bierhaus A, Cooper ME et al. 2010 Disparate effects on renal and oxidative parameters following RAGE deletion, AGE accumulation inhibition, or dietary AGE control in experimental diabetic nephropathy. American Journal of Physiology. Renal Physiology 298 F763-F770. (doi:10.1152/ajprenal. 00591.2009)

Tao JL, Wen YB, Shi BY, Zhang H, Ruan XZ, Li H, Li XM, Dong WJ \& Li XW 2012 Endoplasmic reticulum stress is involved in podocyte apoptosis induced by saturated fatty acid palmitate. Chinese Medical Journal 125 3137-3142. (doi:10.3760/cma.j.issn.0366-6999.2012.17.031)

Tessari P, Garibotto G, Inchiostro S, Robaudo C, Saffioti S, Vettore M, Zanetti M, Russo R \& Deferrari G 1996 Kidney, splanchnic, and leg protein turnover in humans. Insight from leucine and phenylalanine kinetics. Journal of Clinical Investigation 98 1481-1492. (doi:10.1172/ JCI118937)

Thameem F, Farook VS, Bogardus C \& Prochazka M 2006 Association of amino acid variants in the activating transcription factor 6 gene (ATF6) on 1q21-q23 with type 2 diabetes in Pima Indians. Diabetes 55 839-842. (doi:10.2337/diabetes.55.03.06.db05-1002)

Tiwari S, Singh RS, Li L, Tsukerman S, Godbole M, Pandey G \& Ecelbarger CM 2013 Deletion of the insulin receptor in the proximal tubule promotes hyperglycemia. Journal of the American Society of Nephrology $\mathbf{2 4}$ 1209-1214. (doi:10.1681/ASN.2012060628)

Vallon V 2011 The proximal tubule in the pathophysiology of the diabetic kidney. American Journal of Physiology. Regulatory, Integrative and Comparative Physiology 300 R1009-R1022. (doi:10.1152/ajpregu. 00809.2010)

Vallon V, Rose M, Gerasimova M, Satriano J, Platt KA, Koepsell H, Cunard R, Sharma K, Thomson SC \& Rieg T 2013 Knockout of Na-glucose transporter SGLT2 attenuates hyperglycemia and glomerular hyperfiltration but not kidney growth or injury in diabetes mellitus. American Journal of Physiology. Renal Physiology 304 F156-F167. (doi:10.1152/ajprenal.00409.2012) 
Welsh GI, Hale LJ, Eremina V, Jeansson M, Maezawa Y, Lennon R, Pons DA, Owen RJ, Satchell SC, Miles MJ et al. 2010 Insulin signaling to the glomerular podocyte is critical for normal kidney function. Cell Metabolism 12 329-340. (doi:10.1016/j.cmet.2010.08.015)

Wendt TM, Tanji N, Guo J, Kislinger TR, Qu W, Lu Y, Bucciarelli LG, Rong LL, Moser B, Markowitz GS et al. 2003 RAGE drives the development of glomerulosclerosis and implicates podocyte activation in the pathogenesis of diabetic nephropathy. American Journal of Pathology 162 1123-1137. (doi:10.1016/S00029440(10)63909-0)

Wilding JP, Woo V, Soler NG, Pahor A, Sugg J, Rohwedder K \& Parikh S 2012 Long-term efficacy of dapagliflozin in patients with type 2 diabetes mellitus receiving high doses of insulin: a randomized trial. Annals of Internal Medicine 156 405-415. (doi:10.7326/0003-4819-156-6201203200-00003)

Wouters BG \& Koritzinsky M 2008 Hypoxia signalling through mTOR and the unfolded protein response in cancer. Nature Reviews. Cancer $\mathbf{8}$ 851-864. (doi:10.1038/nrc2501)

Xu J, Zhou Q, Xu W \& Cai L 2012 Endoplasmic reticulum stress and diabetic cardiomyopathy. Experimental Diabetes Research 2012827971. (doi:10.1155/2012/827971)
Yan K, Khoshnoodi J, Ruotsalainen V \& Tryggvason K 2002 N-linked glycosylation is critical for the plasma membrane localization of nephrin. Journal of the American Society of Nephrology 13 1385-1389. (doi:10.1097/01.ASN.0000013297.11876.5B)

Ye J, Rawson RB, Komuro R, Chen X, Dave UP, Prywes R, Brown MS \& Goldstein JL 2000 ER stress induces cleavage of membrane-bound ATF6 by the same proteases that process SREBPs. Molecular Cell 6 1355-1364. (doi:10.1016/S1097-2765(00)00133-7)

Yu Y, Thorpe SR, Jenkins AJ, Shaw JN, Sochaski MA, McGee D, Aston CE, Orchard TJ, Silvers N, Peng YG et al. 2006 Advanced glycation end-products and methionine sulphoxide in skin collagen of patients with type 1 diabetes. Diabetologia 49 2488-2498. (doi:10.1007/ s00125-006-0355-8)

Zhang W, Feng D, Li Y, Iida K, McGrath B \& Cavener DR 2006 PERK EIF2AK3 control of pancreatic $\beta$ cell differentiation and proliferation is required for postnatal glucose homeostasis. Cell Metabolism 4 491-497. (doi:10.1016/j.cmet.2006.11.002)

Zinszner H, Kuroda M, Wang X, Batchvarova N, Lightfoot RT, Remotti H, Stevens JL \& Ron D 1998 CHOP is implicated in programmed cell death in response to impaired function of the endoplasmic reticulum. Genes and Development 12 982-995. (doi:10.1101/gad.12.7.982)

Received in final form 28 April 2014

Accepted 25 June 2014

Accepted Preprint published online 30 June 2014
(C) 2014 Society for Endocrinology Printed in Great Britain
Published by Bioscientifica Ltd. 